The Geographical Journal of Nepal

Vol. 13: 167-184, 2020

Doi: http://doi.org/10.3126/gjn.v13i0.28157

Central Department of Geography,

Tribhuvan University, Kathmandu, Nepal

\title{
The Saptakoshi high dam project and its bio-physical consequences in the Arun river basin: A geographical perspective
}

\author{
Dil Kumar Rai ${ }^{1}$ and Tika Ram Linkha ${ }^{2 *}$ \\ ${ }^{1}$ Adaptation for Smallholders in Hilly Areas (ASHA) Project, Government of Nepal/IFAD \\ ${ }^{2}$ Dhankuta Multiple Campus, Dhankuta T.U., Nepal \\ (*Corresponding Author: tika.linkha@gmail.com)
}

Received: 15 November 2019; Accepted: 05 January 2020; Published: March 2020

\begin{abstract}
The big project called Saptakoshi high dam is a bilateral project of Indian and Nepalese government under the Koshi agreement. At present, high dam issue is being the great issue especially raising by the inhabitants of upstream in Koshi basin. Therefore, this research paper attempts to examine the bio-physical consequences due to high dam in the upstream of Arun river basin. Geographic Information System (GIS) and Remote Sensing (RS) technology have been used for the spatial analysis to prepare this paper. Spatial data have been taken from topographical map and Digital Elevation Model (DEM) and the attribute data have taken from Central Bureau of Statistics (CBS), Kathmandu. It revealed that approximately 11777 hectors arable plain land will be inundated in Arun river basin only by water with river deposits due to high dam if the high dam will be built at the proposed place and proposed dam height. The proposed place lies $1.6 \mathrm{~km}$ upstream from Barahakshetra temple of Sunsari district and the dam height will 269 meters. Similarly, more than 10000 population might be displaced in future. There is a strong sense of fear and sadness among the people of affected communities. Till now, they have unknown about the clear information about high dam. As a result, they are sometimes demonstrating against Saptakoshi high dam. So, government should inform and ensure the alternative management of the concerned people in the initial stage to manage the future disputes.
\end{abstract}

Keywords: Arun basin, Bio-physical, Saptakoshi high dam, Koshi Basin 


\section{Introduction}

Saptakoshi high dam is being taken as the highly debatable issue in Nepal. Local people from the dam site and its influence areas are in against of this dam. The main issue raised by them it is supposed to be ambitious project and it might have numerous environmental and social impacts. Thus, local people are in the opposition of this dam and they are obstructing the survey of the dam site. They have written a complain letter to the concerned authorities and threatening to launch a large-scale protest if the detailed project report for the dam was not stopped (Saurabh, 2012). However, Saptakoshi joint commission office claimed that it controls floods on the south east Nepal and northern Bihar of India. Despite it, they also argue this dam will provide year-round irrigation facility to a dozen districts in the eastern and central Terai of Nepal. Additionally, there will also be generation of electricity from this dam.

Nepal, a mountainous country which has more than 6000 rivers and rivulets including big and small (Khatiwada, 2014). Most of these rivers are originating from high Himalayas including Tibet, China and some of the rivers are originating from the Mahabharat and Siwalik (Chure) ranges of Nepal. The major rivers of the Nepal are the Koshi, the Gandaki and the Karnali which are originating from the Himalayas. Among these, the Koshi (also called Saptakoshi because it makes after the integration of different seven tributaries such as Tamor, Arun, Likhu, Indrawati, Sunkoshi, Tamakoshi and Dudhkoshi) river is originating from China and flowing towards Nepal and India. The Koshi river is considered as one of the largest tributaries of the Ganges. The Koshi river and its seven tributaries drain a total area of 69300 square kilometers up to its confluence with the Ganges in India. In Nepal, it is the largest river basin which covers nearly 30000 square kilometers of land of eastern Nepal (Agrawal et al., 2014). On the contrary, Dikshit (2009) claimed that altogether it drains an area of 71500 square kilometers in three countries. Koshi river consists seven major sub-basins and this paper only confined to the Arun river sub-basin. Arun river, the main branch of Koshi is originating from Tibet, China and flowing towards south. Other branches of the Koshi river are originating from different Himalayas/Mountains and flowing towards south east, south west and south. Dudhkoshi, Tamakoshi, Likhu and Indrawati rivers are confluences each other and it flows towards east in the name of Sunkoshi, then after reaching near Triveni in Dhankuta, Arun and Sunkoshi then later Tamor join to each other and flowing downward to the south with the name of Saptakoshi. Hence, the catchment area of Saptakoshi is Kanchanjangha in the east to Gosaikunda in the west of eastern Nepal. This river carries the lots of deposits, gravel and sands every year so, it is bothering in Nepal and India as well. Annually, Koshi river damages a huge arable land, loss of human life and physical properties. It flows with strong current in hilly areas and changes its route in the plain 
land. It has changed its route towards 71.5 miles west in last 214 years from 1736 to 1950 AD (Khatiwada, 2014).

All of the rivers in Nepal which are originating from Himalayas/mountains and flowing down towards India and reach in the Ganga river. Therefore, the work related on river in Nepal affects India and the water issues of Nepal is related with India. The floods coming from Nepal affects India. In this context, some of the treaties are done between India and Nepal for the settlement of the issue of river and water. In the late 1950s, the Indian government built an embankment known as the Koshi barrage under the bilateral agreement on the Koshi river. However, in 2008, the embankment of Koshi river breached and collapsed which displaced millions of people in Nepal and India. Oza (2014) claimed that this embankment breach was not a rare occurrence and the August 2008 event was actually the eighth major breach since the embankments were completed in 1959. Following the 2008 breach, a Nepal-India commission on water resource issued a report stating the need for a new strategy to control the flooding of the Koshi river. Then, the idea of building a multipurpose high dam on the river with the benefit of flood control, irrigation and hydropower had been a subject of discussion between Nepali and Indian government (Oza, 2014). Saptakoshi river is more harmful in the context of flood disaster for both countries but India is more affected than Nepal. Therefore, India has a keen interest to control the Koshi flood and made a plan which is known as Saptakoshi high dam project. It was based on the recommendation of a committee formed under the leadership of A.N. Khosala in 1946 who suggested constructing a dam $1.6 \mathrm{~km}$ upstream of Barahakshetra, Sunsari (Khatiwada, 2014).

The proposed 269-meter-high multipurpose dam on the Saptakoshi river in the Sunsari district of Nepal would provide 3300 Mega Watt (MW) of electricity as well as irrigation facility to India and Nepal together with controlling the flood downstream in Bihar (Oza, 2014). Oza (2014) argued that if dam is constructed, it will displace thousands of people in over 80 Village Development Committees (VDCs) from above the dam site and it will destroy homes, cultures, land and the way of life. Thus the local people are against this high dam for the last 14 years. Although efforts to restart dam planning and construction began in 2008 by Saptakoshi Joint Commission Office yet the local people are objecting to the detail project report.

The high dam is supposed to affect whole bio-physical situations of lower and middle part of Koshi river basin. Hence, it has been a debatable issue in the communities of project areas among the government agencies, local levels and stakeholders of the upstream of river basin. Few studies have been carried out by Oza (2014), Dikshit (2009) and Khatiwada (2014) on the issue of Saptakoshi high dam but they have not 
analyzed its bio-physical impact on the affected areas. Khatiwada (2014) attempted to describe its impact of cultural aspects whereas Oza (2014) focused on the local people perception and their unsatisfaction towards high dam. In this context, the present paper attempts to highlight the bio-physical consequences of Koshi high dam particularly in Arun river basin based on geographical perspective. The bio-physical impact will be spatially distributed in all tributaries of Saptakoshi river however this paper deals Arun river basin only.

\section{Materials and Methods}

\section{Study area}

The Arun river basin is an important geographic region in terms of diverse topographic terrain features, vegetation, wildlife and distribution of population corresponding to socio-cultural phenomenon. The river basin (Figure 1) covers three mountain districts of province number 1 of eastern Nepal: Bhojpur, Dhankuta and Sankhuwasabha. The landscape topography of the basin rises from 123.13 meter (Simle) to 8463 meters (Mt. Makalu) above mean sea level (ICIMOD, 1988). The physiographic or geomorphic shape of the valley is V-shaped conditioned with moderate steep topography terrain and wide range of river trunk in the lower catchment and topography terrain with high steepness and narrow valley in the upstream catchment of the valley. The climatic condition presents its variability based on the diversified on the topography and its altitude e.g. tropical, sub-tropical, temperate climate, alpine and perpetual cold climate. The vegetation and its variability have distributed in terms of climate condition and variability. The total population of this river basin is 504,613 distributing in 111,624 households (CBS, 2012). Agriculture is the prime occupation of the local inhabitants and the patterns of land use have been changing with the change in livelihood options (Koirala, 2006; Subedi and Pandey, 2002).

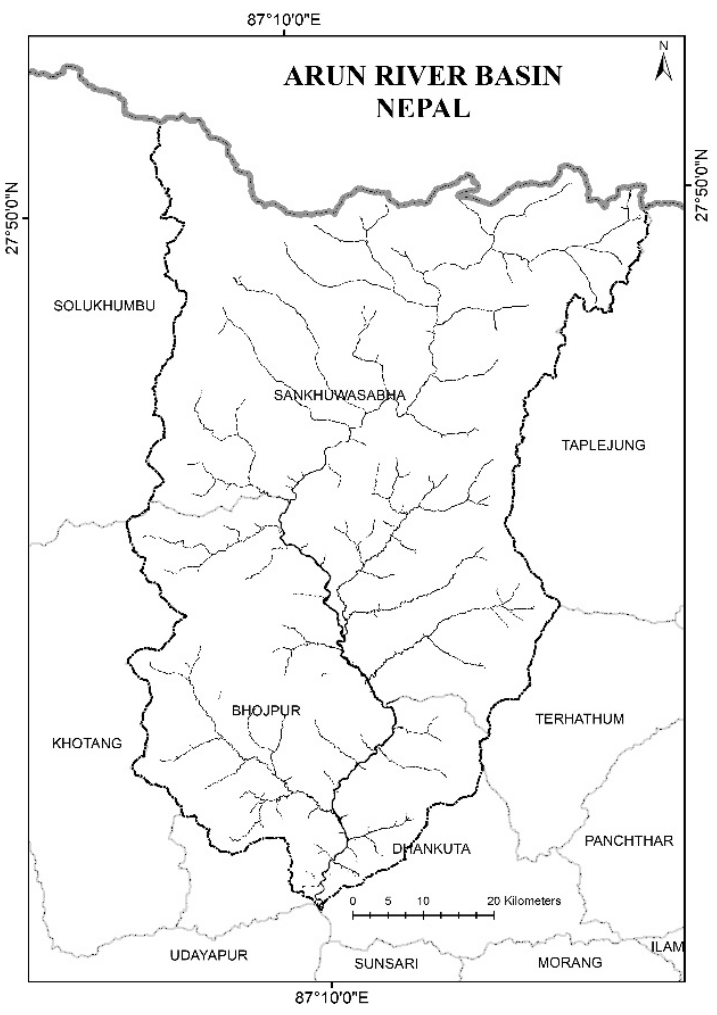

Figure 1: Arun river basin 


\section{Data sources and methods of data preparation}

The GIS tool is primarily adopted in order to analyze the bio-physical and socio-cultural based spatial and non-spatial databases. The altitude of proposed dammed area location is taken as 120 meters msal and the height of proposed dam as 269 meters for the analysis of landforms and topography. As such the actual height of proposed dam will be 389 meters and it is used for GIS based spatial analysis accordingly.

The necessary database is selected on the basis of its authentication, spatial resolution and its spatial accuracy. The spatial data is related to administrative boundary, land use and land cover, hydro-stream network and contour interval derived from the Survey Department, Government of Nepal at the scale 1:25000. The Digital Elevation Model (DEM) representing related landforms and topography generated from contour interval of 20 meters. It is used for topography terrain analysis and distribution analysis of landslide areas based on slope gradients. The land use system known as Abbal, Doyam, Sim and Chahar categorized based on visual image interpretation of land use pattern of toposheet, and Google image and slope contour intervals respectively. A household unit is generated from toposheet map after rectified with respected coordinates system unit and landslide areas, infrastructure, road, bridges, settlement and urban areas extracted from Google images. The largest fresh landslide scars extracted from Landsat- 8 images taken in December 15, 2018. All the spatial data have been projected with World Geodetic System (WGS) 1984 in UTM 44 zone for the spatial analysis.

\section{Result and discussion}

\section{Inundation of upstream land and livelihood at risk}

Saptakoshi high dam is in the process of preparing detail project report with a proposed dam site at $1.6 \mathrm{~km}$ upstream of the famous Hindu temple Barahakshetra in Sunsari district with a proposed height of the dam of 269 meters. If the dam is constructed according to proposed height, there will be inundation of more than 11,777 hectors of upstream land by water in Arun river basin (Figure 2). In the hills, there are huge importance of river basin of lowland for the production where three times crop can be harvesting. As there are very limited agricultural lands in the hills and mountains, therefore, inundation of large agricultural land might cause deficiency of production. Moreover, the surroundings natural environment will be unbalanced which may harm the current state of land, animals, water and bio-diversity. Furthermore, it might cause disasters which will create loss of fertile land, ecosystem and animals. Similarly, due to the proposed high dam in the young Siwalik ranges might make the area vulnerable which creating various future disasters in these regions. 
The extent of land use and land cover is directly linked with the resource management, sustainability and its environmental consequences (Gautam et al., 2003). Changes in the extent and pattern of land use and land cover resulted with different environmental

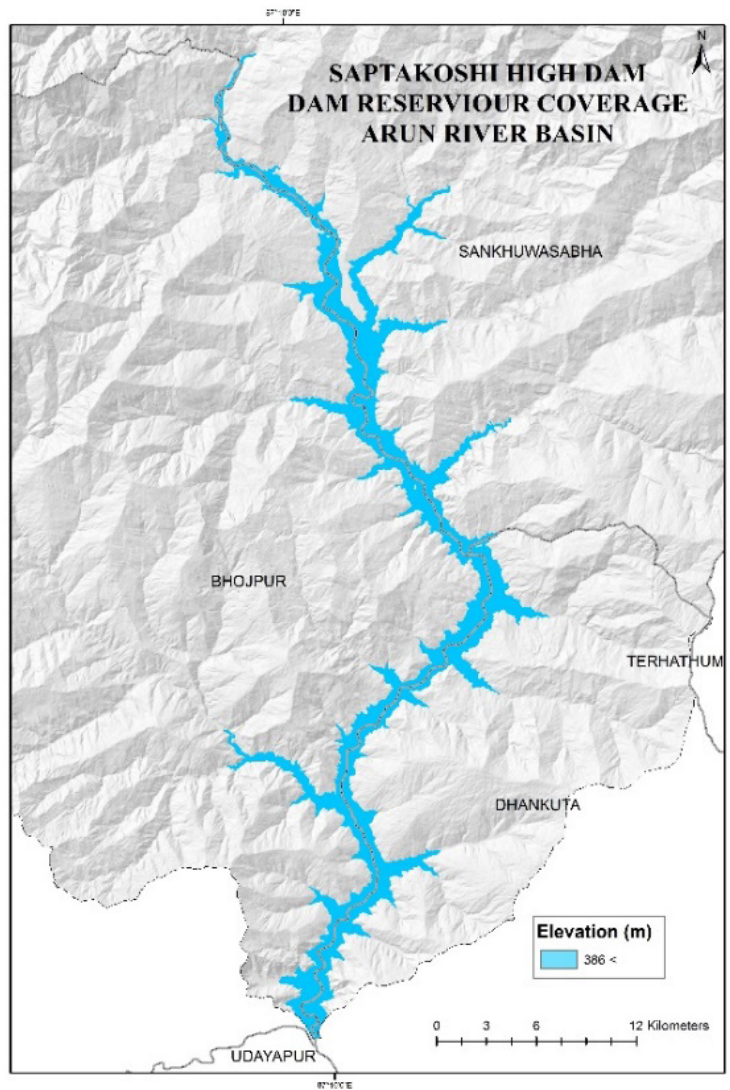

Figure 2: Coverage of Water Dammed due to high dam in Arun river basin

consequences (Ghimire, 2017). Therefore, different types of land use and land cover pattern such as agriculture land, forest, vegetation, shrub, grass and sand dunes will be replaced by dammed water. There are two types of land use pattern including hillslope cultivation and river valley farming system, in which most of the river valley farming system will be affected due to water level rises. The land use of river bed or alluvial plain contains to $A b b a l$ classes characterised by valley cultivation land formed with fine alluvial material with well fertile capacity for production. Hill slope cultivation patches consist of Doyam, Sim and Chahar have less production capacity than river valley cultivation areas. The tropical forest vegetation species suited with tropical climate condition; the inundation by dammed water may result the displacement of vegetation 
species. The existence of several land cover patches like grass and shrub which are contributing supply of fodder to livestock of localities. Displacement of sand dunes with river materials deposited along the sides of the river trunk results in the means of shortage of construction materials in order to building of physical infrastructures and decreases the sources of income of respected local governments.

The calculation of land use land cover features within the inundation area of Figure 2 has been shown in Table 1. The table shows that the inundated area covers agriculture land, forest, sand dune and river bed materials, waterbody including pond or lake and hydro flow line, barren land, grass land, shrub land and cutting and cliff. Within the inundated area agricultural land covers 31.9 whereas forest land shares 32 percent respectively. Similarly, sand dune, bush/shrub and hydro flow line are the other land use/cover to be under the proposed inundated area.

The inundated areas of Arun river basin will cover the different 15 local levels of Dhankuta, Bhojpur and Sankhuwasabha districts. Out of them, Bhojpur and Sankhuwasabha have six local levels and three local levels of Dhankuta district to be directly affected due to high dam. Agricultural land from Mahalaxmi municipality of Dhankuta district will be highly affected by dammed water. Similarly, large agricultural areas of Shalpa Shilicho rural municipality of Bhojpur district and Sahidbhumi rural municipality of Dhankuta district will be affected. Likewise, large forest land of Panchkhapan municipality and Dharmadevi municipality of Sankhuwasabha district and Hatuwagadhi rural municipality of Bhojpur district will also be affected by the proposed dam. 


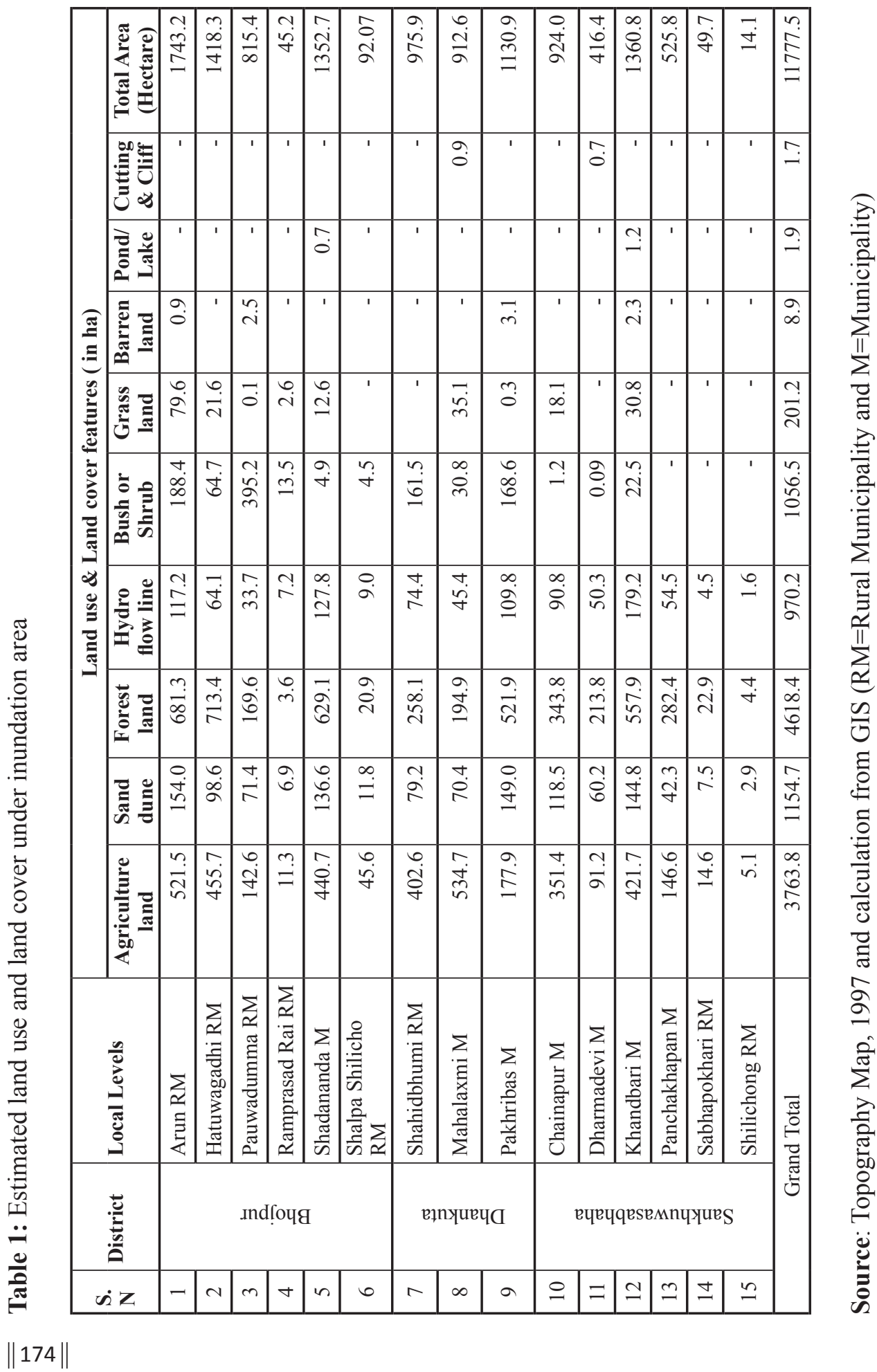




\section{Impact on slope topography, hydro-stream networks and hydro geo-hazards}

The vulnerability has nearly associated with or product of functioning of hazard and risk (Varnes, 1984), in which slope topography and hydro geo-hazards reveal as the major sources of sensitivity indicators of vulnerability (IPCC, 2014; MoPE, 2017). The geomorphic shape of the landscape has moderate to steep topography in the lower catchment and comparatively high steepness and narrow valley in the upstream catchment of the study area. Therefore, slope topography, hydro stream networks and presences and occurrences of hydro geo-hazards events such as landslide, debris and mass wasting have been examined within the high dammed affected areas. It helps to highlight the susceptibility range of vulnerability of community and resources of upstream catchment because geo-hazards event occurrences have always linked with upstream and downstream phenomenon (Nepal et al., 2010).

Table 2 shows the distribution of slope topography which will be affected due to the high dam. Slope gradient can be categorized into five distinct classes i.e., flat, normal, moderate, high and very high. The slope classes consist to above 15 degrees is generally considered as the indicators of active geomorphic functions and operations (Selby, 1993).

Table 2: Estimated inundation slope topography due to high dam

\begin{tabular}{|r|l|r|r|r|r|r|r|}
\hline \multirow{2}{*}{$\begin{array}{r}\text { S. } \\
\text { N. }\end{array}$} & \multirow{2}{*}{ Local Levels } & \multicolumn{5}{|c|}{ Slope topography in dam affected area in (Hectare) } \\
\cline { 3 - 9 } & $\begin{array}{r}\mathbf{r} \mathbf{5} \\
\text { (Flat) }\end{array}$ & $\begin{array}{c}\mathbf{5} \text { to 15 } \\
\text { (Normal) }\end{array}$ & $\begin{array}{c}\mathbf{1 5} \text { to 25 } \\
\text { (Moderate) }\end{array}$ & $\begin{array}{c}\mathbf{2 5} \text { to 45 } \\
\text { (High) }\end{array}$ & $\begin{array}{c}\text { 45<(Very } \\
\text { High) }\end{array}$ & \multicolumn{1}{c|}{ Total } \\
\hline 1 & Arun RM & 395.7 & 407.3 & 512.2 & 422.9 & 16.3 & 1754.5 \\
\hline 2 & Hatuwagadhi RM & 176.8 & 233.8 & 313.0 & 656.2 & 46.5 & 1426.3 \\
\hline 3 & Pauwadumma RM & 156.9 & 170.7 & 215.5 & 263.6 & 14.1 & 820.8 \\
\hline 4 & Ramprasad Rai RM & 18.7 & 16.8 & 9.2 & 2.6 & - & 47.3 \\
\hline 5 & Shadananda M & 429.8 & 374.9 & 386.3 & 170.6 & 1.4 & 1363.0 \\
\hline 6 & Shalpa Shilicho RM & 27.6 & 31.5 & 23.8 & 11.8 & - & 94.7 \\
\hline 7 & Sahidbhumi RM & 116.5 & 174.1 & 228.8 & 413.6 & 31.8 & 964.7 \\
\hline 8 & Mahalaxmi M & 221.4 & 267.1 & 306.7 & 107.0 & 2.9 & 905.1 \\
\hline 9 & Pakhribas M & 218.9 & 192.0 & 297.5 & 390.5 & 23.0 & 1121.9 \\
\hline 10 & Chainapur M & 273.7 & 209.1 & 231.8 & 205.3 & 3.6 & 923.5 \\
\hline 11 & Dharmadevi M & 134.1 & 63.0 & 76.1 & 129.9 & 7.7 & 410.8 \\
\hline 12 & Khandbari M & 518.2 & 301.5 & 282.5 & 252.3 & 4.4 & 1358.9 \\
\hline 13 & Panchakhapan M & 153.1 & 153.3 & 154.2 & 57.5 & 2.9 & 520.9 \\
\hline 14 & Sabhapokhari RM & 32.9 & 14.3 & 4.0 & - & - & 51.1 \\
\hline 15 & Shilichong RM & 11.6 & 3.1 & 0.1 & - & - & 14.8 \\
\hline & Total & 2885.8 & 2612.4 & 3041.6 & 3083.9 & 154.7 & 11777.5 \\
\hline
\end{tabular}

Source: Analysis in GIS 
Approximately, 24 percent flat land (below 5 degree slope) will be inundated by water in Arun river basin due to high dam. These flat lands are the granary of these hill districts and it is called tar in Nepali term. Almost 518 hectare of flat land of Khandbari municipality of Sankhuwasabha district together with 429 hectare of Shadananda municipality and 395 hectare of Arun rural municipality of Bhojpur district will be inundated respectively. Similarly, 22 percent land comprising 5 to 15 degree slope will be inundated due to high dam.

It is considered that the geomorphic processes and functions primarily depends upon the slope of topography. The high dammed water reservoir over the steep and rugged topography will make the topography weak then there will be high chances for landslide, erosion, debris flow and others. Hence, it will create large disasters in the upstream of this high dam area.

Horton $(1832,1945)$ clarifies that drainage density as the product of total length of stream channels divided by the area they occupy. In practical and results, the stream or drainage networks and its spatial density per area units indicate to run-off conditions and degree of dissection of the landscape or topographic terrain (Tucker et al.,2001; Ghimire 2011). The stability of landform and its processes have also primarily determined by the presence of stream networks and its spatial density e.g. higher stream networks and density influences the high degree of dissection of terrain features as a form of geomorphic processes (Strahler, 1952). The condition of river stream network density has examined based on these principles related facts. It also helps to forecast potential future condition of the terrain features with their functions affected by water dammed reservoir and stability of landforms of upstream catchment of dammed water reservoir and vice-versa.

The calculation of drainage networks density is based on the stream length per unit area in the region based on the concept given by Horton in 1932, in which region or area is considered for stream networks occupy on the basis of square kilometer. The calculated spatial density categorized into five distinct classes: very low (0.97-1.62), low (1.62-1.93), moderate (1.93 -2.28), high (2.28-2.69) and very high (2.69-3.44). A several local levels may have suffered from remarkable intensity hillslope processes due to the effect of dammed water reservoir because higher density of drainage influences the high rate and magnitude of geomorphic processes accelerating by presences of water dammed that resulting vulnerability to upstream community and landscape. Arun and Hatuwagadhi rural municipalities of Bhojpur district and Pakhribas and Mahalaxmi municipalities of Dhankuta district might have high chances with various geomorphic processes events of erosion and landslides. 


\section{Possibilities of landslide and erosion}

A landslide is the general name given to the movement of rocks, debris, or earth downslope along a surface of separation by falling, sliding, or flowing. Landslide includes rock falls, deep failures of soil slopes, and shallow debris flows. They result from the failure of the materials which make up a hill slope and are driven by the force of gravity. They are an integral part of the mountain building process and are one of the chief means by which the uplifted mountain mass is transported down to lower valleys and basins. The geometric shape related to landslides and erosion hotspots are generated from Google Earth Pro images that verified through the field work. There seemed 103 landslides and erosion hotspots were mapped containing these 15 local levels. The distribution of landslides is shown in Figure 4. The characteristics of landslide distribution strongly correlates with slope, land use and land cover and presences of stream and its spatial density (Ghimire, 2011). Several studies identified that landslides were distributed either on steep topography or stream network density. The morphometric attributes of these landslides and erosion consist to rock falls, debris falls, debris slides and gully erosion.

The southern aspect of landscape in Jarayotar, Sanodumma and Charambi of Bhojpur district have a remarkable patches of geomorphic hazards events such as gully and rill

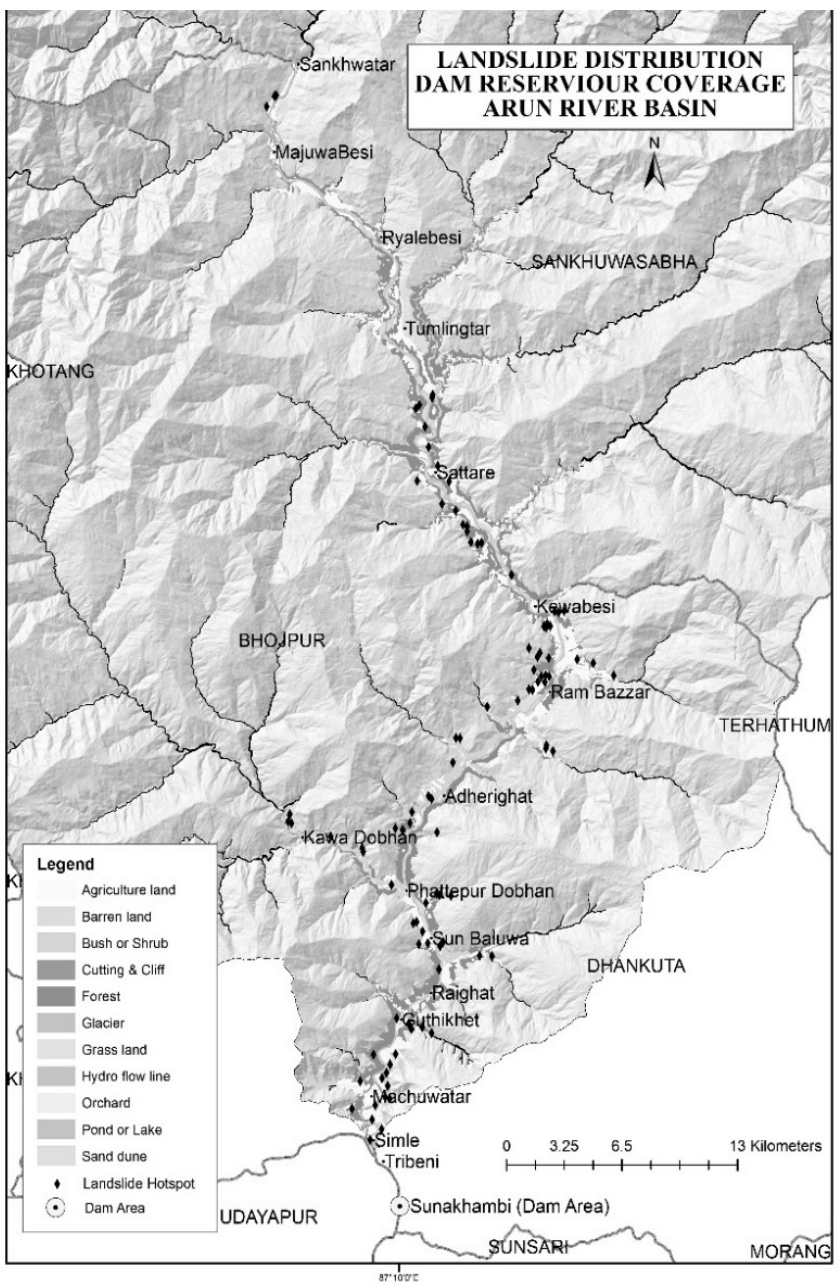

Figure 3: Landslide distribution in high dam affected areas of Arun river basin 
erosion. It reveals that an overall gully and rill patches have not reclaimed and processes and function of events have been same as before or as usual since its creation. The fine soil mixed with sandy red textures have a weighty role to be gully erosion events that strongly support with the condition of stream network density and shrub vegetation cover without grass species. Hence, the pressure and function of gully erosion have been a regular geomorphic process in the southern aspect of landscape topography.

\section{Displacement of settlement and population}

Settlement and population indicate the major aspects of bio-physical phenomenon of any geographical territory with the role on exploitation, management and conservation of resources. A large number of populations, settlement and house units have been existing at possible land which will be inundated by water due to high dam. Basically, the lower plain is the suitable land for agricultural so, people have been living there since ancient time. Some of the market centers are also developing in lower basin of this river. The analysis in Google Earth shows almost, 2269 households which will be affected due to water dammed in this river basin if the high dam height remains 269 meters high in proposed place. In addition, nearly 10263 population are living in these households. So, if the high dam is constructed, government should ready to manage those people who will be directly affected. Beside it, there are also another part which is also indirectly affected due to water dammed.

In terms of human settlement and population more than 4500 people in Bhojpur district might be harmed due to water dammed in their houses particularly in Hatuwagadhi and Shadananda rural municipality of Bhojpur district. Similarly, in Dhankuta district nearly 3000 people might be affected particularly within Mahalaxmi municipality. It is due to Leguwa Bazar which is developing as a market center of this river basin. Perhaps this will be largest local level affected by water in terms of population displacement in Arun river basin. Likewise, nearly 2500 population will be affected in Sankuwasabha district with larger number in Khandbari.

Several studies (Subedi and Pandey, 2000; Koirala, 2006; Linkha and Rai, 2017) on livelihood of communities of in Arun river basin revealed the linkage of lowland and the settlement in uplands areas. The further movement of down site population to up land may trigger ongoing livelihood status of upland as well. 
Table 3: Estimated displacement of household units and population

\begin{tabular}{|c|c|c|c|c|}
\hline \multirow[b]{2}{*}{ S.N. } & \multirow[b]{2}{*}{ Local levels } & \multirow[b]{2}{*}{ District } & \multicolumn{2}{|c|}{$\begin{array}{l}\text { Affected number of household unit and } \\
\text { population }\end{array}$} \\
\hline & & & $\begin{array}{l}\text { Household } \\
\text { Units }\end{array}$ & $\begin{array}{l}\text { Estimated population is } \\
\text { based on average } \mathrm{HH} \text { size } \\
\text { of respective local bodies }\end{array}$ \\
\hline 1 & Arun RM & \multirow{6}{*}{$\frac{\grave{2}}{\frac{2}{2}}$} & 271 & 1255 \\
\hline 2 & Hatuwagadhi RM & & 342 & 1583 \\
\hline 3 & Pauwadumma RM & & 61 & 282 \\
\hline 4 & Ramprasad Rai RM & & 8 & 37 \\
\hline 5 & Shadananda M & & 302 & 1398 \\
\hline 6 & Shalpa Shilicho RM & & 14 & 65 \\
\hline 7 & Sahidbhumi RM & \multirow{3}{*}{ 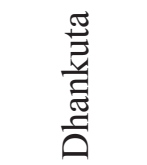 } & 230 & 998 \\
\hline 8 & Mahalaxmi M & & 464 & 2013 \\
\hline 9 & Pakhribas M & & 46 & 200 \\
\hline 10 & Chainapur M & \multirow{6}{*}{ 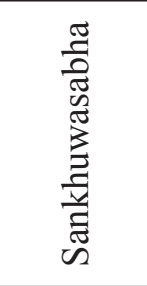 } & 109 & 499 \\
\hline 11 & Dharmadevi M & & 32 & 147 \\
\hline 12 & Khandbari M & & 378 & 1731 \\
\hline 13 & Panchakhapan M & & 12 & 55 \\
\hline 14 & Sabhapokhari RM & & - & - \\
\hline 15 & Shilichong RM & & - & - \\
\hline \multicolumn{3}{|c|}{ Total } & 2269 & 10,263 \\
\hline
\end{tabular}

Source: Google Earth Pro, 2017 (Accessed on 15 October, 2019) and CBS, 2014

There is also socio-cultural and emotional attachment of people with their particular places. The relationship between people and place is deep, dynamic and complex. There are various concepts which refer to people-place relationship. The multidimensional relationship between them is described under several analogous concept. Among the multiplicity constructs, the concept of sense of place is inclusive and broad term for understanding people-place relationship. Sense of place refers to the individual perception of their environment as well as conscious feelings about place. Hence, the concept of sense of place is more interactional and psychological than physical. So, it will very hard to replace the local people from their birth place because of the matter of feelings and loves towards their own soil and environment. Basically, the inhabitants of Arun basin are dominated by indigenous people and they have high level of sense of place than others (Rai, 2017). Indigenous people have the spiritual connection with their land. Still the Kiranti people worship forest, river and other wild animals and these kinds of resources might be affected by the project. On the other hand, Hindu people 
usually follow the traditions of burning their dead bodies on the bank of the rivers. In this situation, the traditional river system will be disturbed due to dam. So, this kind of socio-cultural aspect should be highly considered before the construction of the dam.

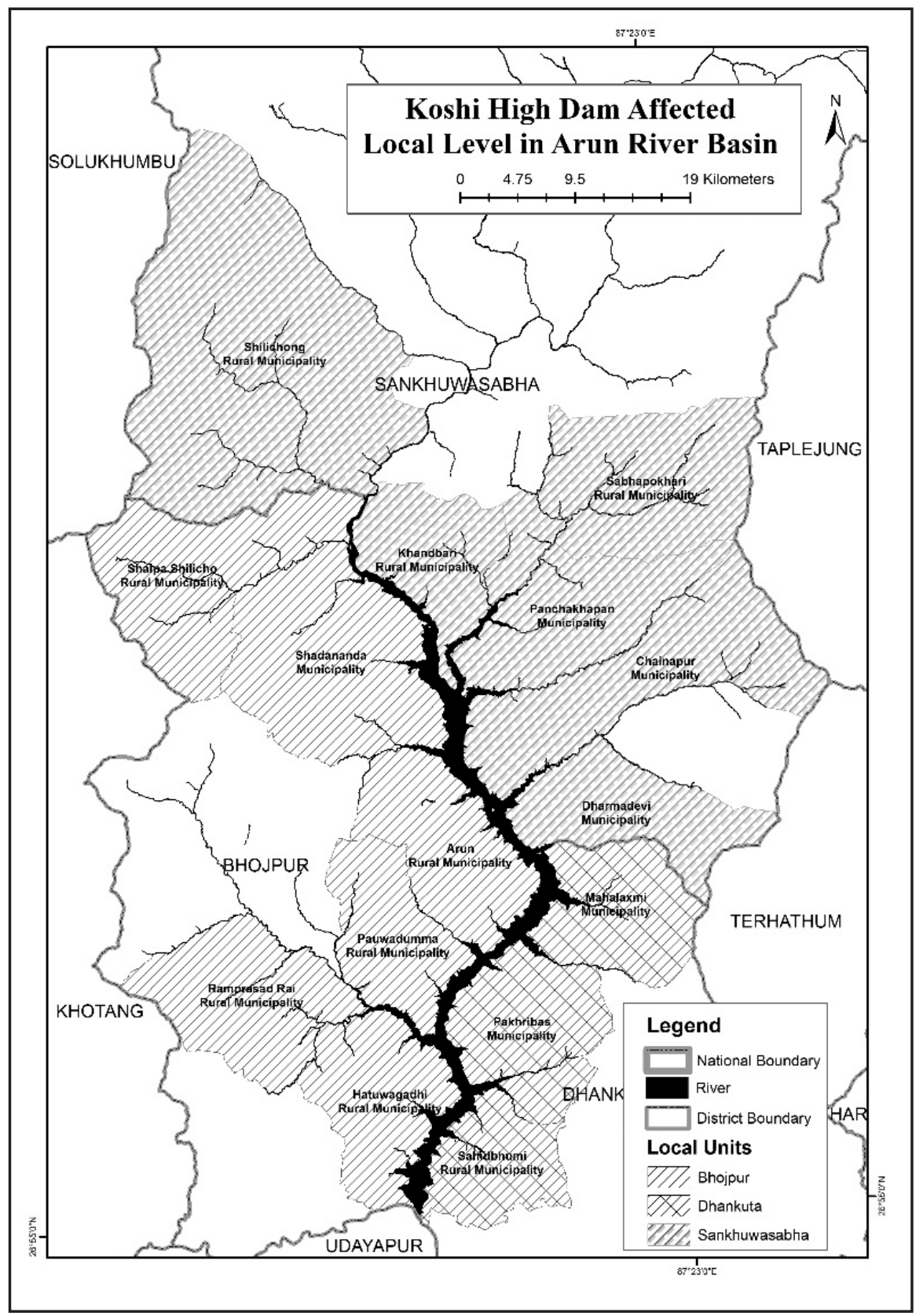

Figure 4: Affected local levels of Koshi high dam in Arun river basin 


\section{Conclusion}

Saptakoshi high dam is going to be constructed with the keen interest of neibouring country rather than Nepal. India has been raising the issue to be addressed from decades although, any concrete action has not taken place so far. However, after the collapse of Saptakoshi embankment in 2008 the interest of India has been increased and now the process of constructing detailed project report of Koshi high dam is on action. Constructing Koshi high dam is now becoming burning issue and argumentative, however, it has some merits as well as demerits too. But the local people are still unknown about real status of this project, they have strong sense of fear and sadness because of unclear information. As a result, they have formed concern groups in order to raise the voice against high dam. In this context, Nepal government should consult them to manage the dispute from the initial stage.

The construction of Saptakoshi high dam at Sunakhambi gorge will affect to the diverse bio-physical phenomenon in the Arun river basin existed below of actual height (389 meter) of dam. It will influence 15 local levels of Bhojpur, Sankhuwasabha and Dhankuta districts if the high dam will be built as per the proposed place and height. As a result, it will badly influence the arable land of eastern hills and mountains. Most of the granary land will be inundated by water then the ecosystem of Arun basin will be unbalanced. Despite it, other several unseen disasters might emerge due to the water pressure on this region. The tropical and sub-tropical vegetation species corresponding to diverse wildlife species will be affected. It will dissolve the indigenous related sociocultural phenomena of particularly Kirant and Hindu ethnic ritual events on hydro mainstream flow. Those communities who are living along the Arun river have very rich religious, cultural norms and values. This high dam would thus mean a great loss for these people, which in many ways, cannot be replaced. The topographic terrain consists of its processes and functioning as a geomorphic process e.g. slope failure, landslide, debris flow and gully erosion will also be led to rise of sensitivity indicators of vulnerability to upland people and communities consequently.

\section{References}

Agarwal, A., Babel, M.S., \& Maskey, S. (2014). Analysis of future precipitation in the Koshi river basin Nepal. Journal of Hydrology 513, 422-434. http://dx.doi. org/10.1016/j.jhydrol.2014.03.047.

CBS (2012). National Population and Housing Census 2011 (National Report). Government of Nepal, National Planning Commission Secretariat, Central Bureau of Statistics, Kathmandu Nepal. 
Dikshit, A. (2009). Kosi Embankment Breach in Nepal: Need for a Paradigm Shift in Responding to floods. Economic and Political Weekly, 44, 70-78.

Gautam, A.M., Webb, E.L., Shivakoti, G.P., \& Zoebisch, M.A. (2003). Land use dynamics and landscape change pattern in a mountain watershed in Nepal. Agriculture, Ecosystems and Environment, 99: 83-96.

Ghimire, M.L. (2011). Landslide Occurrences and its relation with terrain factors in the Siwalik Hills, Nepal: case study of susceptibility assessment in three basins. Nat Hazards, 56, 299-320, doi.10.1007/s11069-010-9569-7

Ghimire, M.L. (2017). Historical Land Cover change in the Chure-Tarai Landscape in the Last Six Decades: Drivers and Environmental Consequences. In A. li et al. (Eds.), Land Cover Changes and Its Eco-environmental Response, Springer Geography, doi. 10.1007/978-981-10-2890-8_5

Horton, R.E. (1932). Drainage basin characteristics. Am. Geophysics. Union, Trans. 13: 348352.

Horton, R.E. (1945). Erosional development of streams and their drainage basins; hydro physical approach to quantitative morphology. Geol. Soc. Am. Bull, 56, 275370 .

ICIMOD (1988). Mountain Environmental Management in the Arun River Basin of Nepal. ICIMOD Occasional Paper No. 9, Kathmandu, Nepal.

IPCC (2014). Climate change 2014: Synthesis report. Contribution of working groups I, II and iii to the fifth assessment report of the Intergovernmental Panel on Climate Change In [Core Writing Team, R. K. Pachauri, \& L. A. Meyer (Eds.)] IPCC, Geneva, Switzerland.

Khatiwada, S.P. (2014). River Capture and Water Issues: An overview of Saptakoshi High Dam Project of Nepal Activity. Anthropology. doi.10.4172/23320915.1000130.

Koirala, H.L. (2006). Livelihood Pattern, Adaptive Strategy and Sustainability of Communities in Southern Arun Valley of Nepal Himalayas. Unpublished Doctoral Dissertation. Geography Department: Guhati University. 
Linkha, T.R. \& Rai, D.K. (2018). The Yakkha: Changing Livelihood Strategies (A Study of Traditional Land of Yakkha). RUPANTARAN. Dhankuta Multiple Campus Dhankuta, 2, 222-235.

MoPE. (2017). Vulnerability and Risk Assessment Framework and Indicators for National Adaptation Plan (NAP) Formulation Process in Nepal. Ministry of Population and Environment (MoPE).

Nepal, S., Flugel, W.A., \& Shrestha, A.B. (2014). Upstream-downstream linkages of hydrological Processes in the Himalayan region. Agriculture, Ecological Process, 3, 1-19.

Oza, J. (2014). Resisting For the River Local Struggle Against the Purposed Saptakoshi River Dam. Independent Study Project (ISP) Collection. 1809. https:// digitalcollections.sit.edu/isp_collection/1809.

Paudel, G.S., \& Thapa, G.L.B. (2004). Impact of social, institutional and ecological factors on land management practices in mountain watersheds of Nepal. Applied Geography, 24: 35-55.

Rai, D.B. (2017). Investigating a Level of Sense of Place among Residents of Sampang,

Bhojpur, Majhkirant. GANTABYA, Progressive Teacher`s Association (NUPTA), 6, 4150.

Selby, MJ. (1993). Hillslope materials and processes (Second Edi). Oxford University Press, Oxford.

Shaurabh (2012). Issue Brief: Re-examining the Indo-Nepal Saptakoshi Dam Project. Indian Council of World Affairs, New Delhi.

Strahler, A. N. (1952). Quantitative geomorphology of drainage basins and channel networks. In V.T. Chow (Eds.), Handbook of applied hydrology. McGraw Hill, New York: 439-476.

Subedi, B. P. and Panday, R. 2002. Livelihood Strategies of Rai Communities in Arun Valley: Continuity and Change. In R.P. Chaudhary, B. P. Subedi, O. R. Vetaas $\&$ T. H. Aase (Eds.), Vegetation and Society: Their Interaction in the Himalayas (157-170). Tribhuvan University, Nepal and University of Bergen, Norway. 
Dil Kumar Rai \& Tika Ram Linkha / The Saptakoshi high dam project ... Vol. 13: 167-184, 2020

Tucker, E.G., Catani, F., Rinaldo, A., \& Bras, R.L. (2001). Statistical analysis of drainage density from digital terrain data. Geomorphology, 36:187-202.

Varnes, D.J.(1984). Slope movement types and processes. In R. L. Schuster, \& R. J. Krizek, (Eds.) Landslide: analysis and control. Special Report 176. Transportation research board. National Academy of Science, Washington:11-33. 